\title{
Preliminary Data Recovery and Mitigation Plan Archaeological Site 41MX5 Morris County US 259: From 2.4 Miles North of FM 44 to 0.5 Miles South of $\mathrm{IH} 30$
}

Follow this and additional works at: https://scholarworks.sfasu.edu/ita

Part of the American Material Culture Commons, Archaeological Anthropology Commons, Environmental Studies Commons, Other American Studies Commons, Other Arts and Humanities Commons, Other History of Art, Architecture, and Archaeology Commons, and the United States History Commons

Tell us how this article helped you.

This Article is brought to you for free and open access by the Center for Regional Heritage Research at SFA ScholarWorks. It has been accepted for inclusion in Index of Texas Archaeology: Open Access Gray Literature from the Lone Star State by an authorized editor of SFA ScholarWorks. For more information, please contact cdsscholarworks@sfasu.edu. 


\section{Preliminary Data Recovery and Mitigation Plan Archaeological Site 41MX5 Morris County US 259: From 2.4 Miles North of FM 44 to 0.5 Miles South of IH 30}

\section{Licensing Statement}

This is a work produced for the Texas Department of Transportation (TxDOT) by the report producer. TxDOT and the report producer jointly own all rights, title, and interest in and to all intellectual property developed under TXDOT's contract with the report producer. The report may be cited and brief passages from this publication may be reproduced without permission provided that credit is given to both TXDOT and the report producer. Permission to reprint an entire chapter, section, figures or tables must be obtained in advance from either the Supervisor of the Archeological Studies Branch, Environmental Affairs Division, Texas Department of Transportation, 125 East 11th Street, Austin, Texas, 78701 or from the report producer. 


\section{PRELIMINARY DATA RECOVERYAND M ITIGATION PLAN ARCHAEOLOGICAL SITE 41MX5}

\section{MORRIS COUNTY}

US 259: From 2.4 Miles North of FM 44

TO 0.5 MILE SOUTH OF IH 30

Texas

State Department of Highways and Public Transportation Highway Design Division

$$
\text { July } 1987
$$




\author{
PRELIMINARY DATA RECOVERY AND MITIGATION PLAN \\ ARCHAEOLOGICAL SITE 41MX5 \\ MORRIS COUNTY, TEXAS
}

I. INTRODUCTION. In the late 1960s, the Texas Highway Department, now known as the State Department of Highways and Public Transportation, (SDHPT) initiated a plan to reconstruct a portion of US 259 in Morris County, Between FM 144, north of Omaha, Texas, and the Bowie County Line. Reconstruction of this highway section would complete modernization of

US 259 and provide a major connection with Interstate 30. The existing highway was to be reconstructed to modern design standards with improvements to vertical alignment and pavement structure. A modern two-lane roadway with $8 \mathrm{ft}$. surfaced shoulders and a $4 \mathrm{ft}$. flush median is to be provided. In March of 1971 a Negative Environmental Declaration for the project was approved and a Notice of Opportunity for Public Hearing was distributed and published. A Public Hearing was held on September 16, 1971. All work on the project was suspended in 1975 due to cash flow problems affecting the SDHPT and the project was not included in the Twenty Year plan. The project was re-activated in 1986 and the Federal Highway Administration (FHWA) project authorization process was completed in 1987. The project was processed as a categorical exclusion, an action consistant with the status of the undertaking as a reconstruction job. In the 1960s, when the project was initiated, there was no provision for on-site cultural resource surveys on projects of this type. It has been determined that an on-site cultural resources survey of the project area was not performed and coordination with the State Historic Preservation Officer, not required at the time of the Negative Environmental Declaration, had not been initiated. The project was let to contract in May of 1987.

II. DISCOVERY OF SITE 41MX5. In July of this year, a member of the cultural resources staff of the SDHPT Environmental and Community Factors Section visited the project. Preliminary clearing of vegetation in the project area had been accomplished by the contractor. At that time, evidence of an archaeological site was observed on the surface and the site was recorded at the Texas Archeological Research Laboratory of the Balcones Research Center, The University of Texas at Austin. The site was given the designation 41MX5. Provision was made for the contractor to avoid the site area. The Office of the State Historic Preservation Officer (SHPO), and the FHWA were notified of the discovery by telephone and by letter dated July 8, 1987. Plans were made for testing operations to begin as quickly as possible. Two staff members proceeded to the site on Monday, July 13th and began testing operations. Results of initial testing indicated that the site should be considered eligible for inclusion in the National Register of Historic Places. The Advisory Council on Historic Preservation was notified of the discovery by telephone, and the SHPO and FHWA were advised by letter dated July 16, 1987 that site 41MX5 was believed to be eligible for the National Register under Criterion D. A meeting was held on Monday, July 20, 1987 concerning Site 41MX5 and attended by representives of the SDHPT, the SHPO, the FHWA, and the Texas Antiquities Committee, as well as by the State Archeologist. The Advisory Council on Historic Preservation was given an opportunity to comment on the proceedings during a conference call held by the participants at this 
This Page Redacted Per THC Policy 
meeting. The SDHPT is providing twenty-four guard at the site to prevent vandalism.

III. DESCRIPTION OF SITE 41MX5AND RESULTS OF TESTING. Site 41MX5 is located some $3600 \mathrm{ft}$. north of the White Oak Creek bridge on the west side of US 259. The location is shown in Figure 1. The site is situated on the westernmost portion of a ridge isolated by Murphy Branch to the west and one of its small tributaries to the north. The ridgetop overlooking the Murphy Branch and White Oak Creek floodplains to the west and south rises some 20-25 ft. above the floodplain. Before recent clearing, the area was heavily wooded with oak forest. The site was evidenced by the presence of ceramic sherds and flint debitage located on two distinctly higher points or knolls. Testing operations were centered around these knolls.

A. Field Testing Methods. A series of three 2 by 2 meter and four 1 by 1 meter hand-dug test units were placed in deposits on and around the two small knolls. Test Unit 1 was placed on the westernmost knoll, the smaller of the two and the one located furthest from US 259 (Fig. 2). This unit produced two circular stains in the first level and Test Unit 3 was excavated adjacent to Test Unit 1 in order to see if a pattern of post-holes could be discerned. No such pattern was found. Ceramic sherds, a few chips, some very small bone fragments, and a Gary-like projectile point were found in levels 1 and 2 of Test Unit 1 . Test Unit 3, the adjacent unit, produced a ceramic bowl adjacent to the east wall. There was evidence of very deteriorated boney material under the bowl, possibly indicating the cranium of a human burial (Fig. 3). The north wall profiles of Test Units 1, 3, and 4 are shown in Figure 4.

Test Unit 2 was placed in the larger of the two small knolls, the one located closest to the highway. This 2 x 2 meter unit yielded four pottery vessels in level 4, including a globular jar, a small bowl, another bowl, and a sherd from yet another vessel (Fig. 5). Test Unit 4 produced occasional flakes and sherds and a chert cobble. Test Units 5, 6, and 7 produced no cultural material. The west and north profiles of Test Unit 2 are shown in Figure 6.

Materials recovered include grog and bone tempered ceramics, a trait suggestive of Sanders affiliation. However, decorative elements present at the site include Avery Engraved and Nash Neck Banded examples, which tend to suggest Texarkana or McCurtain affiliations.

B. Determination of Eligibility. On Friday, July 17, 1987, materials recovered from Site 41MX5 were returned to the SPHPT Archaeological Laboratory in Austin, Texas. Here the materials were examined and field records reviewed. Based upon the evidence for human burials as well as associated grave goods in a relatively undisturbed context, Site 4IMX5 is believed to meet the criteria for inclusion within the National Register of Historic Places. The SHPO was informed of this by letter. On Monday, July 20, 1987 during the meeting with the SHPO, a concurrence determination of eligibility was agreed upon between the representatives of the SDHPT, the SHPO, and the FHWA. 


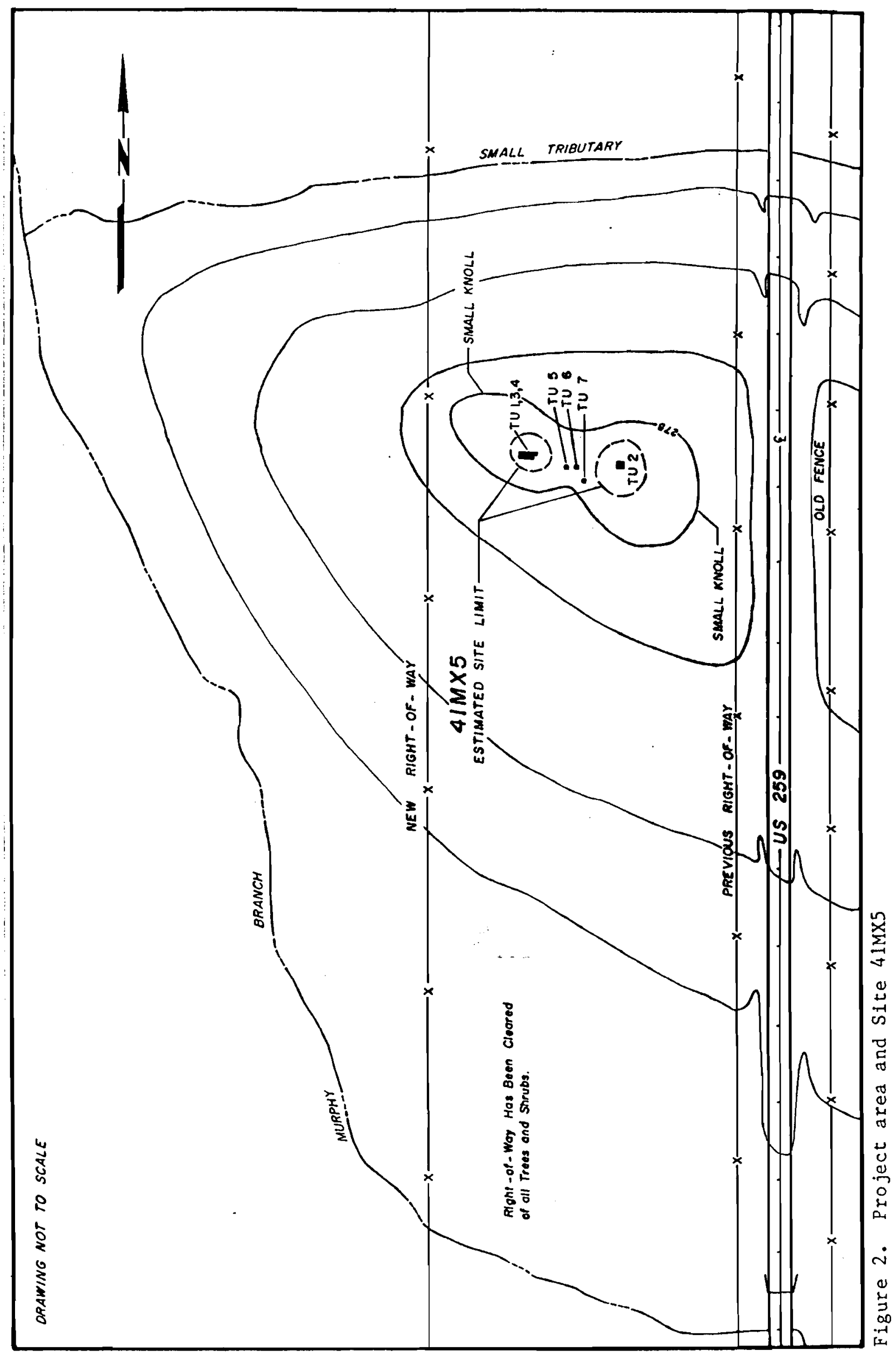


IV. DATA RECOVERY AND MITIGATION PLAN FOR SITE 41MX5. Because Site $41 \mathrm{MX} 5$ was discovered following award of contract, rapid recovery of all potentially valuable data is imperative. Expeditious recovery is also mandated by the presence in the area of avid relic collectors and commercial "pothunters" who, if given the opportunity, would most certainly vandalize this site. At the meeting referred to above and held on Monday, July 20, 1987, these factors were taken into consideration. A number of steps were agreed upon by those present as appropriate for the recovery of data from Site 41MX5, and also as necessary for the evaluation of other cultural resources potentially threatened by this project. These steps were presented to the Advisory Council on Historic Preservation by telephone for comment and preliminary approval. The following Preliminary Data Recovery and Mitigation Plan is submitted as directed by the Advisory Council.

A. Initial Mitigative Measures

1. A thorough pedestrian survey of the entire project will be completed as quickly as possible in order to determine if other cultural properties are present within the project area. Results of this survey will be submitted to the office of the State Historic Preservation Officer. Likely localities within the project area will be shovel tested in an attempt to locate buried cultural materials. This survey will be conducted during the week of July 20, 1987.

2. The area on the east side of US 250, across the highway from the small knolls and Site 41MX5, will be thoroughly tested by hand and by machine in an attempt to locate any additional cultural evidence associated with 41MX5. Specifically, village remains or areas of more extensive burials will be sought. This testing will be initiated during the week of July 20, 1987.

3. The State Archaeologist will immediately notify the Texas Indian Commission of the discovery of human burials at Site 41MX5 and the Indian Commission will be requested to immediately notify the Chief of the Caddo Indians. The Texas Indian Commission and the Caddo Elders will be kept informed of the progress of the excavations and are free to visit the site at any time. The Caddo Elders will be consulted as to their wishes concerning disposition of any human skeletal material recovered from the site.

B. Intrasite Analysis. Site 41MX5 may represent a ceramic period occupation with a single episode of occupation. The site may consist of a small cemetary, without an associated village discernable within the project right of way, or it may represent a small habitation area or hamlet associated with nearby fields, with the burials located in the houses. Data Recovery operations at Site 41MX5 should be directed towards recovery of the following information:

1. Confirmation of the age and single component status of Site 41MX5 by increasing the number of diagnostic artifacts and samples of datable materials. It is currently believed that Site 41MX5 is of late Caddoan affiliation. However, stylistic and technological aspects of the ceramics recovered to date leave some question as to the exact date and cultural affiliation of the occupation represented at site 41MX5. 


\section{$41 M \times 5$ \\ TEST UNIT 3 \\ LEVEL 2}
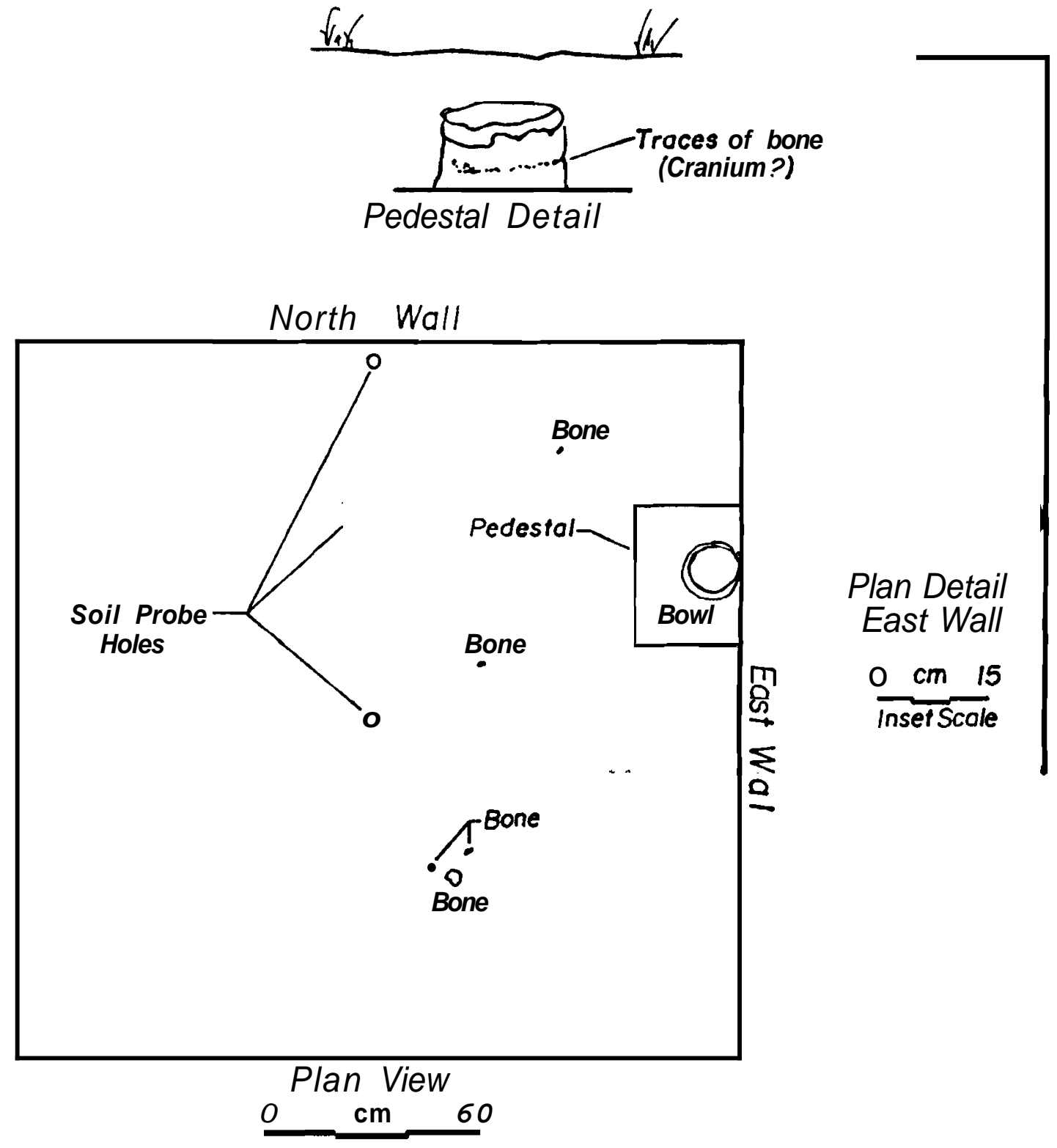

Figure 3. Plan view of Test Unit 3, Level 2. 


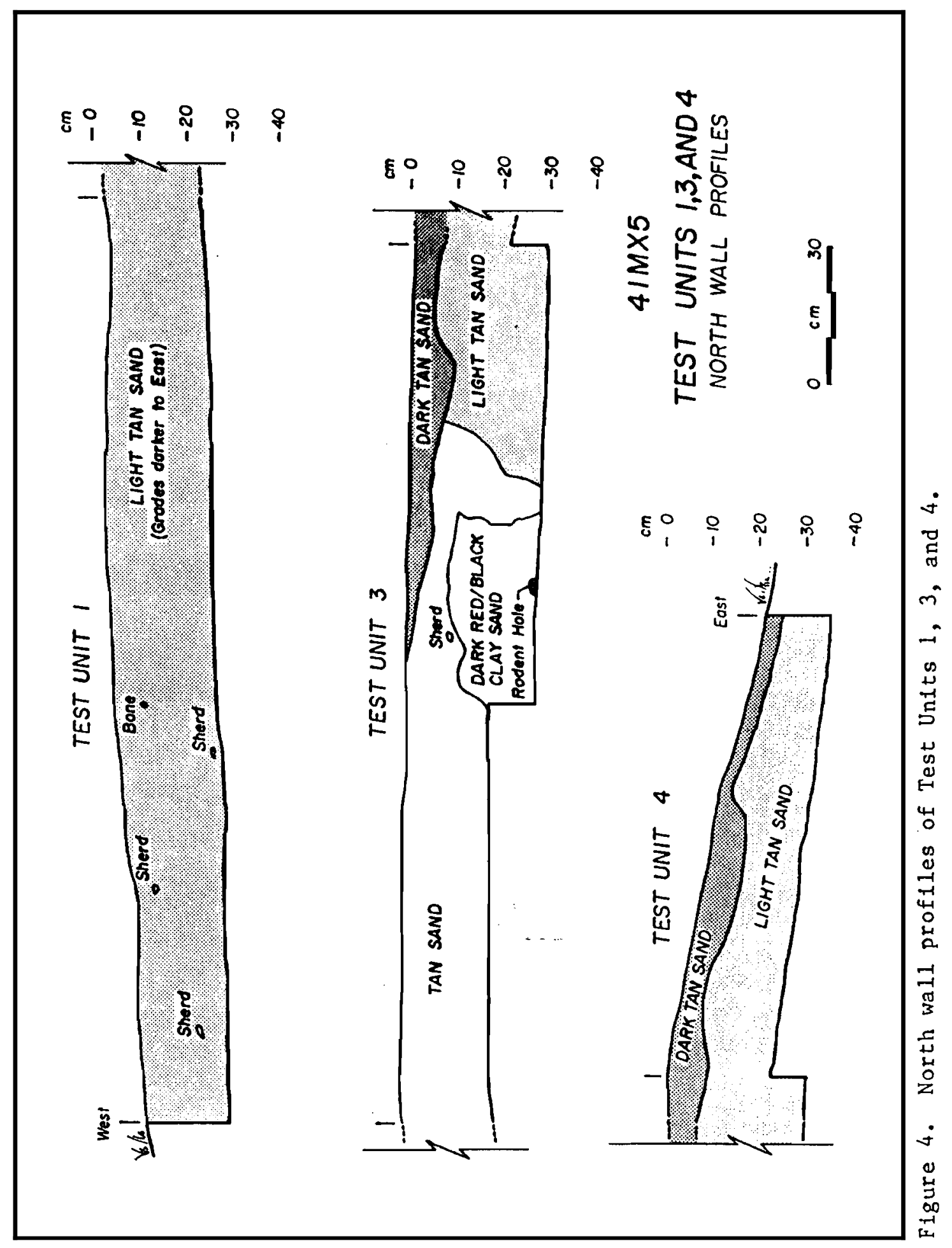




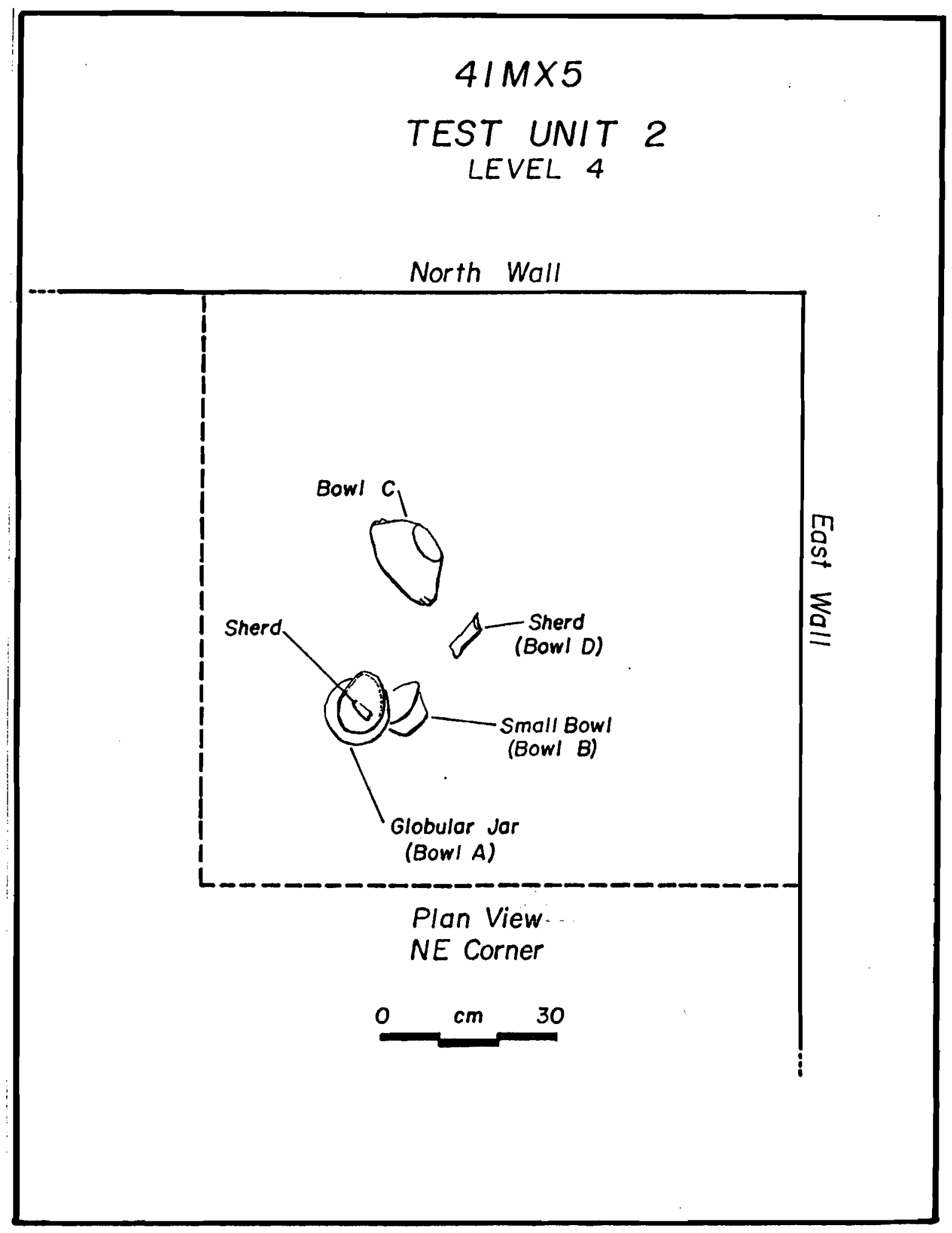

Figure 5. Plan view of the northeast quadrant of Test Unit 2, Level 4 . 
2. Determination of the functional status of the site. Does it represent a small cemetary, or does it represent burials located within house structures? Is there an associated village nearby?

3. Refinement of the cultural stratigraphy at the site and elucidation of the horizontal distribution of cultural remains by precise block excavation. The productive areas of the two knolls will be completely excavated in large block units, with a block excavation to be centered on each knoll. Additional units will be placed on the periphery of the knolls in order to test for additional cultural remains. It is anticipated that a block of six 2 by 2 meter units will cover the easternmost knoll, while the slightly larger knoll nearest to the road can be covered with a block of ten 2 by 2 meter units. All deposits except those showing obvious disturbance from recent cleating activities will be troweled. Any cultural material encountered will be plotted in place, and the floor of each $10 \mathrm{~cm}$. level will be cleaned and mapped. Cultural features such as possible post-hole stains, pits, or concentrations of ceramics or bone, will be treated as discrete features. If such features are found near to the wall of a unit, the evidence will be retained in place in a pedestal and the adjacent unit opened up so that the feature can be treated as a single unit. Any cultural features such as pits, hearths, burial offerings or human skeletal remains will be carefully documented in situ. All associated artifacts and faunal remains will be carefully recorded. Any potentially datable materials will be recovered and appropriate special studies performed.

C. Intersite Analysis. The ongoing research program at Cooper Lake has produced extensive information about sites of Caddoan affiliation. Four major interdisciplinary research themes are guiding the work at Cooper Lake. These are: (1) settlement patterning, (2) local environmental conditions, and ecology, (3) subsistence practices and technologies, and (4) disgnostic and significant material culture remains (Randall W. Moir, et. al., 1987). Although information from Site 41MX5 is currently limited, it is hoped that study of the cultural remains and archaeological data eventually recovered from the site will provide useful information concerning these major themes as applied to the period of late Caddoan occupation.

In the Cooper Lake studies, the position of Cooper Lake on the periphery of the Caddoan area has raised the question of the extent to which these peoples were part of an autonomous cultural group or merely a part of a population centered downstream which participated fully within the Caddoan lifestyle. Materials from Site 41MX5, centrally located within the Caddoan area, should provide an interesting comparison with the late Caddoan materials recovered from sites in the Cooper Lake region. Basic questions concerning the sociocultual interaction sphere remain to be answered for Site 41MX5. It has yet to be determined whether the main cultural affiliation and trade network derive from the Texarkana Focus along the Texas Arkansas border to the northeast or the McCurtain Focus from north along the Red River. It has also yet to be determined what influences derive from the south, i.e. Whalen Complex influence (Karen Doehner and Richard E. Larson, 1978). 
D. Analysis of Material Culture. Ceramic and lithic analyses are anticipated to be the main components of an analysis of material cultural remains.

1. Lithics. While present, lithics do not make up the main element of the material cultural represented at site 41MX5. It is possible that the site represents a small cemetary, and the presence of chipping debris and other evidence of the manufacture of lithic tools would not be expected. Lithic tools do not seem to be substantially represented as mortunary offerings, at least from the burials recovered in the testing phase of the excavations. However, an analysis of the lithic component as found at the site will include the following: (1) a description of the morphological and stylistic attributes of the tools present, and (2) a discussion of the raw materials utilized and material sources. Diagnostic artifacts shall be fully described, measured, and illustrated. The typological classifications used shall be consistant with regional nomenclature. The lithic reduction strategy will be examined, if material recovered provides sufficient examples for such strategy to be determined. Horizontal clustering of artifacts will be delineated in an attempt to identify activity areas and/or activity related tool-kits. If such tool-kits can be identified, they will be examined for evidence of ecological adaptation, subsistance strategy, and/or indications of cultural change. Cryptocrystaline materials will be described using color, inclusions, texture, and other properties to distinguish different varieties, and an attempt will be made to isolate sources of these raw materials. The potential for patterns of raw material acquisition to aid in delineating trade networks and resource procurement ranges will be explored.

2. Ceramics. Ceramics represent the main element of material culture present at Site 41MX5. If the site does indeed consist of a small cemetary, this may continue to be the case. It is hoped that a ceramic sample will be obtained sufficient to allow meaningful comparisons with other Late Caddoan period sites. Analysis of ceramics will include delineation of standard morphological and stylistic attributes and a discussion of the ceramic technology. Sherds will be examined along fresh breaks under appropriate magnification. It is hoped that such analysis will help to identify intrasite and intersite relationships. The ceramic types present will be examined for any indications of cultural affiliation as well as for evidence of trade networks and cultural change. Any ceramics which cannot be placed in a typological category will be fully described and included in the analysis.

3. Ground Stone Tools. It is anticipated that gound stone tools such as manos, milling basins, and nutting stones may be encountered. In addition, hematite and other minerals showing evidence of modification may occur as grave offerings. Such items will be described and illustrated and an attempt will be made to locate the source of raw materials utilized in the manufacture of such tools.

4. Bone and Shell Tools. Preservation of bone at Site 41MX5 would appear to be very poor and recovery of modified or unmodified bone is expected to be minimal. Any bone or shell tools recovered will be fully described, 
discussed, and illustrated. Horizontal and vetical distribution of these tools will be determined, and comparisons with the bone and shell components of other Caddoan sites will be made.

5. Unmodified faunal remains. Again, due to the poor preservation of osteological material, recovery of unmodified faunal remains is not expected to be great. All faunal materials recovered will be analyzed as follows: A qualified individual shall identify these remains as to genus and species, sex, number of individuals represented, pathologies, and evidence of butchering or other human alteration. All faunal material will be analyzed and those specimens too fragmentary to be identified as described above, will be placed in an appropriate larger category (e.g. fish, small mammal, bird, large mammal, etc. ).

6. Human Remains. It is known that human remains are present at the site. Preservation of the human skeletal material has been very poor, and it is not yet known to what extent traditional anthropometric and other studies can be carried out. In addition, the views of the representatives of the Caddo People must be sought before certain types of studies should be initiated. It is hoped that it will be possible to obtain basic demographic data from the skeletal remains including sex and age data. The nature of the remains may allow for certain special studies such as an analysis of stable carbon isotopes in an attempt to determine certain facts about diet, etc. However, it may not be possible to do traditional paleopathological studies due to the extremely fragmentary nature of the material.

V. DATA RECOVERY METHODS. Data recovery efforts at Site 41MX5 will be undertaken according to the following procedures:

A. Information Search. Full use will be made of previous research conducted in regions adjacent to Site 41MX5. Additional information will be sought from (1) published and unpublished scholarly manuscripts, reports, books, journals, theses and dissertations; (2) The files and data from various institutions and agencies will be utilized as appropriate including those of Texas A\&M University, the University of Texas at Austin, the Texas Archeological Research Laboratory of the Balcones Research Center, and the Texas Historical Commission; and (3)

consultation with qualified professionals known to have knowledge of and interest in the cultural resources of the project area, and knowledgeable local informants.

B. Data Recovery Through Excavation. The following delineates minimum excavation requirements for the recovery of data at Site 41MX5. The Principal Investigator and Field Investigator have the discretion to direct placement of units and trenches and to direct additional work applicable to the research problems indentified. It may be necessary to revise excavation strategies as data recovery proceeds. The following excavations shall be carried out: 
1. The two small knolls shall be investigated by means of block excavations centered around the highest point of each knoll. Contiguous 2 by 2 meter units shall form the excavation blocks. A minimum of 6 such units shall make up the block on the westernmost knoll, while the block on the larger knoll closest to the road shall consist of a minimum of 9 such units. Excavation procedures shall be directed towards the careful exposure of in situ artifacts and features, and the identification of habitation or living surfaces. Natural stratigraphic units will be followed where possible, and vertical levels will be no greater than $10 \mathrm{~cm}$. Excavation will be carried out into sterile subsoil.

Additional 1 by 1 meter test units will be excavated into the slopes of the knolls. A stratigraphic trench will be excavated to connect the two small knolls in order to determine their stratigraphic and geomorphological relationship.

Following the excavation procedures as outlined above, any remaining top-soil will be stripped from the knolls by machine in order to look for evidence of additional features or other evidence of habitation.

In order to assure that these guidelines are followed, the following standard excavation procedures will be required.

2. Standard Procedures.

A. The Principal Field Investigator will maintain a complete field journal of daily activities. This journal will be open to inspection at any time. Thorough excavation records shall be maintained and shall include site maps drawn to scale, plan maps of excavation units and trenches, profiles of excavation units, and photographic documentation of all excavation units and of materials and features recovered. Records shall be of sufficient detail to allow future researchers to identify the area and extent of excavation and the horizontal and vertical associations of all materials recovered.

B. All measurements shall be made in the metric system.

C. Horizontal control. A grid shall be established and a plane table or equivalent map of the excavation area shall be produced showing the precise location of all excavation units and trenches. The established grid shall be tied in to a known elevation above mean sea level.

D. Vertical control. Excavation shall be by natural stratigraphic units where these are discernable. Such natural units shall be subdivided into arbitrary units of no more than $10 \mathrm{~cm}$.

E. All matrix contained within burial pits wil be recovered and returned to the laboratory for fine screening and floatation. All other matrix shall be screened through 1/4 in. hardware cloth. Soil samples will be taken from all features as well as from selected profiles. 
F. Stratigraphic profiles shall be recorded for at least one wall of each excavation unit and for selected portions of any backhoe trenches. These profiles shall be recorded by scale drawings, black and white photographs and color transparencies.

G. Each excavation level with its associated features and artifacts shall be documented by scale diagrams, black and white photographs and color transparencies. The date of excavation, the workers, and a brief description of the stratum and and any findings shall be recorded for each level in each excavation unit.

H. Features shall be given a unique designation and this shall be consistently used in the field records. Features shall be excavated in such a way as to obtain a view of the cross-section where appropriate. Features shall be recorded by scale drawings and profiles, as well as by black and white photographs and color transparencies.

I. A complete photographic record will be kept of the progress of work at the site, and of units as they are excavated, in addition to photographic documentation of any features or unusual finds. Photographs shall be documented in a photographic log and shall be identified as to subject, location, date, and view.

J. All artifacts, and human, faunal, and botanical remains from the site shall be processed and catalogued and detailed provenience for each item shall be maintained.

K. All potentially datable materials shall be recovered and processed in a manner appropriate for use in radiometric analysis.

IV. PREPARATION OF A TECHNICAL REPORT OF FINDINGS. A report of investigations shall be prepared which shall meet current professional standards as specified in the Council of Texas Archeologists (CTA) Guidelines (1984) and shall be suitable for publication in the SDHPT Highway Design Division series Publications in Archaeology.

A. The report shall consist of the following sections:

(1) Title Page

(2) Abstact

(3) Introduction

(4) Methods and Problem Orientation

(5) Work Conducted

(6) Analysis of Information Recovered

(7) Summary Statement

(8) Bibliography

(9) Appendices (maps, artifact descriptions, special studies, statistical analyses, tables, graphs, and charts as appropriate.)

Information shall be presented in textual, tabular and graphic formats as deemed appropriate. All references utilized shall be cited in the bibliography. 
B. Review. The final report shall be subject to both internal and external review by interested professionals, and shall be presented to the SHPO for review and comment.

C. Report format. Reports of investigations shall be prepared in a format reflecting contemporary standards as specified in the Council of Texas Archeologists (CTA) Guidelines (1984).

D. Report distribution. Printed copies ofthe final report will be made available for sale to the public. Fifteen copies will be provided to the Texas Historical Commission and 65 copies will be sent to the Texas State Library and Archives for distribution throughout the state. Complimentary copies shall be made available to interested professionals within the state.

VI. PERSONNEL, SCHEDULING, AND CURATION

A Personnel. The Principal Investigator will be Dr. Frank A. Weir, Director of Archaeological Studies for the Environmental and Community Factors Section of the Design Division of the State Department of Highways and Public Transportation. Field investigation will be under the direction of Alan J. Wormser, with the assistance of Jerry Henderson, both members of the SDHPT professional cultural resources staff. Alan J. Wormser will be in charge of analysis and preparation of the final report.

B. Scheduling. Project scheduling is anticipated to be as follows:

1. Field Work: conducted from July 14, 1987 through August 14, 1987

2. Laboratory processing of materials recovered: completed by December of 1987

3. Analysis: completed by December of 1988

4. Final Report: completed by July of 1989 .

C. Curation. Cultural materials recovered from 41MX5 shall be the property of the State of Texas. All artifacts, level forms, maps, photographs, and other notes from the project shall be stored at the archaeological offices of the SDHPT until final disposition of these materials in a proper curational facility is determined. 
BIBLIOGRAPHY

Bousman, C. Britt, Michael B. Collins, and Timothy K. Perttula

1986 Quaternary Geomorphology At Cooper Lake: A Framework For Archaeological Inquiry. Report of Investigations, Number 5. Prewitt \& Associates, Inc. Austin. Review Draft.

Campbell, T. N., ed.

1961 Symposium: Relationship Between the Caddoan Area and Neighboring Areas. Bulletin of the Texas Archaeological Society. Vol. 31 (3).

Davis, E. Mott, ed.

1959 Proceedings of the Fourth Conference on Caddoan Archeology. Bulletin of the Texas Archaeological Society. Vol. 30.

Doehner, K., and R. Larson

1978 Archaeological Research at Cooper Lake, Northeast Texas, 1974-1975. Research Report Number 108. Archaeology Research Program, Southern Methodist University, Dallas.

Doehner, K., D. Peter, and S. A. Skinner

1978 Evaluation of the Archaeology at the Proposed Cooper Lake. Research Report Number 114. Archaeology Research Program, Southern Methodist University, Dallas.

Moir, Randall W., Duanne E. Peter, David H.E. Jurney, Dan McGregor, and Jeff Girard 1987 A Preliminary Research Design for Archaeological and Historical Investigations Cooper Lake, Delta and Hopkins Counties, Texas. Archaeology Research Program Institute for the Study of Earth and Man, Southern Methodist University, Dallas. Preliminary Draft.

Timothy K. Perttula, B. D. Skiles, M. B. Collins, M. C. Trachte, and F. Valdez, Jr. 1986 "The Everlasting Sand Bed": Cultural Resources Investigations at the Texas Big Sandy Project, Wood and Upshur Counties, Texas. Reports of Investigations, Number 52. Prewitt \& Associates, Inc. Austin.

Scurlock, J. Dan

1962 The Culpepper Site, A Late Fulton Aspect Site in Northeastern Texas. /bu Bulletin of the Texas Archeology Society. Vol. 32.

Wycoff, Don G., and Linda Ragland Fisher

1985 Preliminary Testing and Evaluation of the Grobin Davis Archaeological Site 34Mc-253, McCurtain County, Oklahoma. Archeological Resource Survey Report Number 22. The University of Oklahoma. 